\title{
ABORSIE AS MORELE DILEMMA IN SUID-AFRIKA
}

\author{
HS Humpel, H Strydom
}

\section{INLEIDING}

Sedert 1996 is die terminering van swangerskap op versoek wettig in Suid-Afrika. Ongeag die standpunte wat daarvoor of daarteen ingeneem word, het die terminering van swangerskap deel van die etos van die Suid-Afrikaanse samelewing geword. Die samelewing moet daarom geleer word hoe om dit te hanteer en hoe om aan diegene wat deur die daad van aborsie geraak word, hulp te verleen (De Vynck, 1999:1).

Enige een wat deur die terminering van swangerskap gekonfronteer word, moet hom/haar op ' $\mathrm{n}$ kontinuum van ekstreme plaas alvorens hy/sy enige besluit kan neem. Dit is dus noodsaaklik om op hoogte te wees van historiese feite, relevante wetgewing en filosofiese, etiese en ander aspekte rakende aborsie (Schwindack, 1995:5). Kennis van die geskiedenis en die ontwikkeling van gewettigde aborsie verbreed ' $\mathrm{n}$ mens se begrip van aborsie as ' $\mathrm{n}$ morele dilemma in Suid-Afrika. Hierdie artikel bespreek die historiese verloop van aborsie asook die ontwikkeling daarvan vanaf die stadium van onwettige aborsies tot die hedendaagse geliberaliseerde aborsiewetgewing. In aansluiting by die stelling van Forrest (1994:8) dat die terminering van swangerskap altyd morele en etiese dilemmas impliseer, fokus hierdie artikel op aborsie as ' $n$ morele dilemma wat aspekte soos mediese, maatskaplike, kulturele, godsdienstige en etiese aspekte, asook bevolkingsbeleid insluit.

Hierdie artikel beoog om aborsie as morele dilemma vanuit ' $n$ Suid-Afrikaanse perspektief te bespreek en aan te dui dat verskeie morele vrae rakende hierdie onderwerp steeds onbeantwoord bly. Die volgende aspekte ten opsigte van aborsie word dan ook in hierdie artikel onder die loep geneem, naamlik:

- dat kennis aangaande die historiese agtergrond van aborsie in Suid-Afrika dit makliker maak om die gekompliseerdheid daarvan as morele dilemma te begryp;

- dat wetgewing riglyne waaraan morele waardes gemeet kan word, bied;

- dat die huidige aborsiewetgewing insgelyks die terminering van swangerskap sanksioneer, wat vanselfsprekend ' $n$ morele dilemma meebring; en

- dat terminering van swangerskap voorkom kan word deur 'n bevolkingsbeleid van doeltreffende gesinsbeplanning.

\section{PROBLEEMSTELLING}

Aborsie is ' $n$ morele dilemma wat bykans so oud soos die mensdom self is. Dit gee aanleiding tot verskeie vrae oor die regte van die fetus, die betekenis, kwaliteit en omskrywing van menslike lewe, die vrou se rol in die hedendaagse samelewing, haar reproduktiewe regte en die regte van die indiwidu teenoor díe van die samelewing asook oor seksuele waardes en norme (Forrest, 1994:12). Aborsie is ' $n$ werklikheid in die hedendaagse samelewing en dit maak deel uit van die morele verval. Die onderwerp terminering van swangerskap is emosioneel gelaai en vandag net so relevant as in die vroegste jare. Alhoewel verskillende politieke oplossings aan die hand gedoen word, staan die aborsiedebat wesenlik los van politieke oplossings. Die mens word reeds van kindsbeen af geleer om ' $n$ morele leefstyl, wat beskou kan word as ' $n$ uitdrukking van sy/haar geloof en beginsels, te ontwikkel. Sodoende word ' $n$ mens se morele waardes in gedrag vergestalt. 
Wetgewing bied ' $\mathrm{n}$ basis waarop morele waardes gebaseer kan word (Kretzschmar \& Hulley, 1998:5). Alhoewel die stryd rakende die aanvang van lewe en meningsverskille in die aborsiedebat voortduur, is die Wet op Vrugafdrywing en Sterilisasie (Wet 2/1975) herroep en met die Wet op Keuse oor die Beëindiging van Swangerskap (Wet 92/1996c) vervang. Vroue kan nou veilig en vertroulik swangerskappe op versoek termineer.

Aborsiewetgewing maak aborsie nie vanselfsprekend in die gemeenskap aanvaarbaar nie. Dit is ook nie altyd in ooreenstemming met die sosiale waardes en norme van ' $n$ spesifieke gemeenskap nie. Ten spyte daarvan dat aborsie sedert 1996 in Suid-Afrika gewettig is, bestaan daar steeds ' $n$ moeilik oorbrugbare gaping tussen wetgewing ten opsigte van aborsie en die werklikheid daarvan. Aborsiewetgewing waarborg nie noodwendig ' $n$ verandering in oortuigings, houdings en gedeelde belange soos geslagsrolle, seksualiteit en ouerskap nie (Mojapelo-Batka, 2000:4). Verskeie faktore is verantwoordelik vir die bestaande teenkanting met betrekking tot aborsie op versoek, want dit word beskou as ' $\mathrm{n}$ bedreiging vir die gevestigde gedragspatrone, soos tradisionele geslags- en seksuele verhoudings en ander aspekte van die maatskaplike lewe soos tradisionele standpunte van verskillende kultuurgroepe (Mojapelo-Batka, 2000:2). Beskikbare statistiek oor wettige aborsies dui aan dat aborsie op aanvraag na die implementering van aborsiewetgewing op 1 Februarie 1997 toegeneem het (Anon, 1998:7). Ten opsigte van tienerswangerskappe en aborsie kom 'n toename ook wêreldwyd voor (Abortion Statistics, 2000:1-4; Guttmacher, 1999:1-10). Sedert die aanvanklike onwettige uitvoering daarvan tot en met die huidige aborsiewetgewing het aborsie as onderwerp in Suid-Afrika in sensitiwiteit toegeneem. Die aantal aborsies op versoek het toegeneem, die aborsiedebat is aangevuur en aborsie het ' $n$ morele dilemma gebly. Daar bestaan geen definitiewe antwoorde op vrae rakende hierdie aktuele onderwerp met sy diep morele inslag nie. Aborsie moet in die geheel begryp word, aangesien dit deel geword het van die etos van die heersende samelewing regoor die wêreld - ook in Suid-Afrika.

\section{OMSKRYWING VAN BEGRIPPE}

- Aborsie/terminering van swangerskap is volgens Rulashe (1999:3) gedefinieer as “... the interruption of pregnancy before the period when the fetus is viable (capable of living a separate existence)." Aborsie en terminering van swangerskap word afwisselend in hierdie artikel gebruik.

- Spontane aborsie (miskraam) is "n natuurlike beëindiging van 'n swangerskap as gevolg van sekere patologiese toestande waaroor die swanger vrou en mediese praktisyn geen beheer het nie (Rulashe, 1999:3).

- Terapeutiese aborsie verwys na mediese ingrepe om ' $n$ swangerskap te beëindig in gevalle waar die vrou se gesondheid of lewe bedreig word indien swangerskap voortgesit word of waar die gesondheid van die fetus as gevolg van genetiese faktore bedreig word (Mojapelo-Batka, 2000:17).

- Geïnduseerde aborsie is ' $n$ doelbewuste poging om op 'n kunsmatige wyse 'n einde aan 'n swangerskap te maak met die doel om die swangerskap te beëindig (Rulashe, 1999:3).

- Draagtyd is die tydperk van swangerskap van ' $n$ vrou, bereken vanaf die eerste dag van die menstruele periode wat met betrekking tot die swangerskap die laaste is (Wet op Keuse oor die Beëindiging van Swangerskap, Wet 92 van 1996c, 1996:1302).

- Nasciturus-beginsel geld in " $n$ geval waar die ongeborene geag word as reeds gebore tot sy/haar voordeel. Die beginsel word toegepas in gevalle waar status asook erfreg van toepassing is (Davel, 2000:3). 
- Konsepsie/bevrugting begin in " $n$ breukdeel van ' $n$ sekonde in een van die twee fallopiusbuise van die vrou wanneer 'n sperm (manlike geslagsel) en 'n eiersel (vroulike geslagsel) verenig, aldus Louw, Van Ede en Louw (1999:101).

- Kontrasepsie word deur Mogano (1999:5) gedefinieer as “... the act or practice of preventing sex from resulting in the woman becoming pregnant."

\section{HISTORIESE AGTERGROND}

\section{Vroeë geskiedenis van aborsie}

Die vroegste verwysings na aborsie kom in Chinese geskrifte van 2696-1737 v.C. voor (Le Roux, 1995:30). Volgens Haasbroek (1999:8) en Mkhize (2000:16) het geskrifte van onder andere Filo van Alexandrië, Barnabas en Tertullianus reeds aborsie-verwante sake aangeraak. Hierdie filosowe het geglo dat moederskap ' $n$ vrou se plig teenoor haar man en die staat was en dat aborsie dus toegepas moes word om bevolkingsgroei te beperk. Die meerderheid Grieke was teen aborsie gekant. Hippokrates het alreeds 460-370 v.C. aborsie in sy bekende Eed van Hippokrates verbied. Alhoewel die Romeinse samelewing van 750 v.C. nog primitief was, is aborsie toe reeds as " $n$ probleem $n$ geïdentifiseer. Volgens die Romeinse Reg was die fetus eers by geboorte ten volle mens en in hierdie patriargale stelsel het die vader oor aborsie besluit (Hawthorne, 1982; Le Roux, 1995:30-31).

Die Didache, die vroegste dokument in die geskiedenis van die kerk (2e eeu n.C.), het die vroeë kerk se houding jeens aborsie weerspieël, naamlik dat dit verbied is en dat diegene wat wel aborsie ondergaan het, skuldig was aan moord (Le Roux, 1995:31).

\section{Internasionale geskiedenis van aborsie}

In die vroeë 20ste eeu het aborsie deel uitgemaak van die kriminele kodes in al 50 state van Amerika. Aborsie om die moeder se lewe te red, was die enigste uitsondering (Sekudu, 2001:103). Uitstaande internasionale gebeure ten opsigte van die wettiging van aborsie was onder andere die alombekende Hooggeregshofsaak in die VSA, naamlik Roe versus Wade soos deur Forrest (1994:20) aangedui: "The court ruled that the State could not intervene in the abortion decision between a woman and her physician during the first three months of pregnancy." Politieke meningsverskil en agitasie oor aborsie is hierdeur aangevuur. Volgens die literatuur los die aborsiewetgewing nie die probleem ongewenste swangerskappe op nie (Van Rooyen, 1998:295). Die situasie in die VSA word beskryf as " $n$ pynlike en intense stryd ten opsigte van aborsie, aangesien aborsiewetgewing geen oplossing vir genoemde probleem bied nie (Van Rooyen, 1998:295).

In Engeland was aborsie onwettig, en is slegs toegelaat indien die moeder se lewe bedreig is. In 1936 is aborsies gewettig. Liberalisering van wetgewing in Brittanje het gedurende 1966 plaasgevind met die uitvaardiging van wetgewing wat aborsie op versoek toelaat (Sekudu, 2001:113). In Nederland is gedurende 1980 die terminering van swangerskap op versoek tot 12 weke van draagtyd onder streng voorwaardes toegelaat. ' $n$ Verpligte wagtydperk van vyf dae tussen die eerste dag van berading en die prosedure is ingestel om aan die swanger vrou wat aborsie oorweeg, geleentheid te bied om 'n finale besluit te neem (Sekudu, 2001:110).

\section{Suid-Afrikaanse geskiedenis van aborsie}

Die Suid-Afrikaanse perspektief oor aborsie het teen genoemde internasionale agtergrond ontwikkel. 
Giftige wortels en kruie is gedurende die jare 1840 tot 1910 algemeen as abortiewe middels gebruik (McCulloch, 1996:3). Volgens Dondashe (2000:1) is die gebruik van kruiemiddels as aborsiemetode gedurende 1870 opgevolg met kommersiële aborsiemedikasie. Sommige vroue het geaborteer, ander het gesterf, en nog ander het na mislukte aborsiepogings selfs selfmoord gepleeg. Alhoewel die eertydse regering, naamlik die tydperk tot 1996, oortuig was daarvan dat vrywillige aborsie nie deel sou uitmaak van die Suid-Afrikaanse leefwyse nie, was agterstraataborsies aan die orde van die dag. Vroue het ook gesterf as gevolg van self-geïnduseerde aborsies (Forrest, 1994:22). Gedurende die 19e eeu het die sendelinge wat na Suid-Afrika gekom het, vroue daarvan bewus gemaak dat aborsie 'n ernstige sonde is (Manxaile, 1998:20).

Gedurende die tydperk 1910-1960 is meer chirurgiese metodes al meer by aborsie gebruik weens die ontwikkeling van die mediese tegnologie wêreldwyd. Suid-Afrika het in die veertigerjare meer afgesonder geraak en pogings om aborsie te wettig, het gaandeweg verminder. Gedurende 1948 is toenemende teenkanting ten opsigte van aborsie op grond van morele, godsdienstige, rasse- en politieke gronde ontvang (McCulloch, 1996:3). Die Nasionale Regering het aborsie slegs indirek goedgekeur, naamlik wanneer die swanger vrou se lewe in gevaar was (Mkhize, 2000:31).

\section{WETGEWING EN JURIDIESE ASPEKTE VAN ABORSIE}

Wetlike bepalings oor aborsie kan wêreldwyd, aldus Le Roux (1995:57), in vier kategorieë ingedeel word soos in Tabel 1 aangedui, naamlik:

\section{TABEL 1}

\section{WETLIKE BEPALINGS VAN ABORSIE}

\begin{tabular}{|l|l|}
\hline Onwettige aborsie & Aborsie is geheel en al verbied en geen uitsondering word gemaak nie. \\
\hline Beperkende aborsie & Aborsie word slegs in lewensgevaarlike omstandighede toegelaat. \\
\hline Voorwaardelike aborsie & $\begin{array}{l}\text { Aborsie word op grond van eugenetiese en humanitêre faktore soos } \\
\text { verkragting en bloedskande asook breë gesondheidsfaktore toegestaan. }\end{array}$ \\
\hline Liberale aborsie & Aborsie op versoek. Die besluit oor aborsie berus by die swanger vrou. \\
\hline
\end{tabular}

\section{Tydperk voor 1975}

Die Suid-Afrikaanse reg is op die Romeins-Hollandse Reg geskoei en is ook deur die Engelse Reg beïnvloed. Aborsie as misdaad is net so uit Nederland oorgeneem en is geensins statutêr in SuidAfrika bepaal nie (Le Roux, 1995:57; Manxaile, 1998:20; Ndhlovu, 1999:11). Ten opsigte van aborsie stel die Romeins-Hollandse Reg dat aborsie geregverdig is in uiterste gevalle waar voortgesette swangerskap die moeder se lewe sou bedreig (McCulloch, 1996:3; Rau, 1996:2). Aborsie in Suid-Afrika was ' $\mathrm{n}$ gemeenregtelike misdaad, met ander woorde dit is deur oorgelewerde en ongeskrewe gebruike en wette hanteer (Le Roux, 1995:68). Dit was ' $n$ wetsoortreding om ' $\mathrm{n}$ aborsie onder enige omstandighede te bekom, aldus Geldenhuys en De Lange (2001:92).

Aborsiewetgewing in Suid-Afrika is genoodsaak deur ontwikkelings in die mediese wetenskap, die vroeë identifisering van misvorming by die fetus en veranderde gemeenskapsopvattings oor aborsie (Le Roux, 1995:68). Voortvloeiend hieruit was die Aborsie en Sterilisasie Wetsontwerp wat uiteenlopende reaksie ontlok het (Mkhize, 2000:38; Rau, 1996:3). 


\section{Wet op Vrugafdrywing en Sterilisasie (Wet 2 van 1975)}

Hierdie wet vervang die Gemeneregbepaling, naamlik dat aborsie ' $n$ misdaad is behalwe onder sekere omstandighede, soos in gevalle waar die swanger vrou se lewe in gevaar verkeer of haar fisiese gesondheid bedreig word, of indien 'n risiko vir fisiese en geestesafwyking van die fetus bestaan (Le Roux, 1995:68; Wet op Vrugafdrywing en Sterilisasie, Wet 2 van 1975, 1975:3).

Die wet maak nie voorsiening vir aborsie op versoek nie, wat impliseer dat vroue met ongewenste swangerskappe die praktyk om hulle tot onwettige en onveilige agterstraataborsies te wend, moet voortsit. Toestemming tot aborsie is nie pertinent in hierdie wet vervat nie. Dit het aanleiding gegee tot die Wetsontwerp op die Beëindiging van Swangerskap, 1996 (Le Roux, 1995:74; Manxaile, 1998:21, 26).

\section{Die Grondwet van die Republiek van Suid-Afrika (1996) en aborsie}

Met menseregte in gedagte en die Handves vir Menseregte in die Suid-Afrikaanse Konstitusie, is die finale produk van die terminering van swangerskap in Oktober 1996 in die parlement aanvaar. Die uitdaging wat aan die land gestel is, was om die konsep van die Westerse samelewing (menseregte en indiwidualisme) met Afrika-standpunte (kulturele en stamverwante praktyke) te versoen (Manxaile, 1998:41). Alle wette is ondergeskik aan die Grondwet wat regte van indiwidue beskerm. Die Grondwet (1996) het 'n nuwe bedeling ten opsigte van demokrasie en menseregte ingelei. Dit beskerm die vrou se reg om ' $\mathrm{n}$ aborsie te versoek, waarvoor huidige wetgewing (Wet op Keuse oor die Beëindiging van Swangerskap, Wet 92 van 1996c) voorsiening maak.

\section{Wetsontwerp op die Beëindiging van Swangerskap, 1996}

Volgens die Wetsontwerp het die vrou reproduktiewe reg. Die uitgangspunt is dat swangerskap in die vrou se liggaam plaasvind en sy is die enigste persoon wat kan besluit of die swangerskap beëindig moet word al dan nie (Mkhize, 2000:40). Derhalwe is slegs die swanger vrou se toestemming tot aborsie nodig (Wet op Keuse oor die Beëindiging van Swangerskap, Wet 92 van 1996, 1996(b):5).

\section{Wet op Keuse oor die Beëindiging van Swangerskap (Wet 92 van 1996)}

Aborsiewetgewing beoog om ' $n$ veilige metode vir die terminering van swangerskappe in ' $n$ gesonde en higiëniese omgewing te vestig. De Pinho en Hoffman (1998:786) huldig die mening dat indien dit higiënies en korrek gedoen word, die aborsieprosedure as veilig beskou word. Sterftes en ander gevolge van onveilige aborsies word dus tot die minimum beperk. Die regering is bewus daarvan dat niks ' $\mathrm{n}$ swanger vrou wat vasbeslote is om haar ongewenste swangerskap te termineer, sal keer nie. Wetgewing maak dit vir vroue moontlik om te besluit of hulle met die swangerskap wil voortgaan en kinders in liefde en goeie sorg in die wêreld te ontvang of die swangerskap wil termineer (Mkhize, 2000:88).

Volgens die inleiding van die Suid-Afrikaanse Wet op Keuse oor die Beëindiging van Swangerskap $1996 \mathrm{c}$ is die terminering van swangerskap nie ' $\mathrm{n}$ vorm van geboortebeperking of beheer oor bevolkingsgrootte nie (Mkhize, 2000:3; Wet op Keuse oor die Beëindiging van Swangerskap, Wet 92 van 1996, 1996(c):1302). Aborsiedienste is toeganklik vir alle swanger vroue, ongeag ouderdom, woonplek of sosio-ekonomiese status, wat hulle swangerskappe tot 12 weke van draagtyd wil termineer (Ndhlovu, 1999:11). Tussen die 13de en 20ste week van draagtyd kan ' $n$ swangerskap getermineer word indien ' $n$ mediese praktisyn van mening is dat voortgesette swangerskap die lewe van die moeder of fetus bedreig. Na die 20ste week van 
draagtyd kan aborsie slegs gedoen word na oorleg met nog 'n mediese praktisyn om te verseker dat voortgesette swangerskap lewensbedreigend vir die moeder of die fetus is (Mkhize, 2000:2).

Wetgewing omskryf ook waar aborsies uitgevoer moet word en wie toestemming vir die terminering van aborsies moet gee (Mkhize, 2000:40; SA, 1996(c):1304). 'n Swangerskap kan beëindig word met die ingeligte toestemming van slegs die swanger vrou, tensy sy nie in staat is om sodanige toestemming te gee nie. "In the case of a pregnant minor, defined as a female person below the age of 18 years, a medical practitioner or registered midwife must advise such minor to consult with her parents, guardian, family member or friends before the pregnancy is terminated" (Davel, 2000:10). Sodanige terminering van swangerskap mag egter nie geweier word indien ' $n$ swanger minderjarige nie van voorneme is om genoemde persone in kennis te stel van die terminering van haar swangerskap nie (Wet op Keuse oor die Beëindiging van Swangerskap, Wet 92 van 1996, 1996(c):1306).

\section{Implikasie van die huidige wetgewing, 1996}

Sedert die Wet op Keuse oor die Beëindiging van Swangerskap (Wet 92 van 1996c) op 1 Februarie 1997 in werking getree het, is wye reaksie ontlok (Manxaile, 1998:21). Verskeie aborsieklinieke het die lig gesien. In 'n poging om aborsie as alternatief te ontmoedig, het tehuise vir ongehude moeders opgeskiet, aanneming is aangemoedig, kerke het hulle deure oopgemaak vir vroue wat aan armoede blootgestel is en berading is gegee ten opsigte van besluitneming en oorweging van alternatiewe (Mkhize, 2000:88). Lewensvatbaarheid is deur vorige wetgewing, Wet op Vrugafdrywing en Sterilisasie (Wet 2 van 1975), as 26 weke na konsepsie beskou. In huidige wetgewing, Wet op Keuse oor die Beëindiging van Swangerskap (Wet 92 van 1996c), is dit weggelaat (Sekudu, 2001:101). Alhoewel verskeie kontrasepsiemiddels vir die doel van geboortebeperking beskikbaar is, is Kretzschmar en Hulley (1998:89) van mening dat aborsie as konstrasepsiemetode gebruik sal word.

Teenstrydige nasionale reaksie het voorgekom. Enersyds was die algemene mening gehuldig dat die fetus ' $\mathrm{n}$ reg op lewe het en dat hierdie bepaling onkonstitusioneel is. Andersyds is gepleit dat die konstitusionele regte van die swanger vrou vooropgestel moet word deur aan haar 'n geleentheid tot keuse te bied (Davel, 2000:11). Die ongeborene se belange word deur die nasciturus -beginsel beskerm, maar indien die moeder besluit om die swangerskap te laat termineer, kan niemand haar daarvan weerhou nie. Rau (1996:4) is van mening “... that the Constitution does not expressly provide that the right of life includes fetal life." Dit impliseer dat die fetus nie dieselfde regte soos na geboorte geniet nie, want regspersoonlikheid begin by geboorte. Wetgewing ignoreer nie die feit dat ' $n$ fetus ' $n$ lewende wese is nie, maar dit bepaal dat die regte van die swanger vrou dié van die fetus oorheers (Mkhize, 2000:41).

Teenstanders van aborsie in mediese kringe wys daarop dat aborsie teen die mediese kode indruis (Mkhize, 2000:5). Die Wetsontwerp het voorsiening daarvoor gemaak dat mediese praktisyns wat teen deelname aan aborsieprosedure gekant is, hulle van hierdie prosedure mag distansieer (Wetsontwerp op die beëindiging van swangerskap, 1996c:80-96). Huidige wetgewing, Wet op Keuse oor die Beëindiging van Swangerskap (Wet 92 van 1996b) beklemtoon dit nie dermate nie. Wetgewing dwing mediese praktisyns nie om die terminering van swangerskap teen hulle wil of beginsels uit te voer nie. Hulle mag egter nie die swanger vrou wat aborsie wil ondergaan, teenstaan nie en moet sodanige vroue na die korrekte hulpbronne verwys. Wetgewing respekteer die godsdienstige en morele oortuigings van die mediese praktisyn, maar verwag ook dat respek betoon moet word vir die swanger vrou se begeerte om haar ongewenste swangerskap te laat termineer (Mkhize, 2000:11). 
Diegene wat teen aborsiewetgewing gekant is, is van mening dat die saak oor die terminering van swangerskap te ver gevoer is. Die wet beperk die persoon onder die ouderdom van 18 jaar in talle opsigte, maar nie ten opsigte van 'n versoek om 'n swangerskap te termineer nie. Geen voorsiening word ook vir die regte van die biologiese vader gemaak nie. Die biologiese vader, wat ' $n$ aandeel in die swangerskap het, behoort volgens hulle ook inspraak te hê (Mkhize, 2000:41).

Suid-Afrikaners is steeds gewikkel in ' $n$ pynlike en intense stryd oor wettige aborsie. Aborsiewetgewing los nie probleme ten opsigte van 'n ongewenste swangerskap op nie; dit ontketen ander probleme en het die aborsiedebat aangevuur (Van Rooyen, 1998:295). Die twee standpunte, pro-lewe- en pro-keuse-beweging, handhaaf ' $\mathrm{n}$ nimmereindigende debat.

\section{ABORSIE - 'N MORELE DILEMMA}

\section{Moraliteit}

Volgens Kretzschmar en Hulley (1998:20) gee moraliteit aan die indiwiduele persoon oriëntering en betekenis in die lewe. Dit bied ' $n$ oplossing vir huidige maatskaplike probleme en is onontbeerlik omdat dit lewensbedreigende probleme van die hede en toekoms onder die loep neem.

Die sedelike regverdigheid van aborsie veroorsaak ' $n$ etiese dilemma in die samelewing wat uiteenlopende standpunte ontlok. Persepsie speel hier ' $n$ belangrike rol. Dit gaan nie hoofsaaklik om diskriminering teen die swanger vrou wat aborsie versoek nie, maar dit raak geloofsoortuigings en waardes aan wat in ooreenstemming met die realiteit van aborsie gebring kan word, aldus Ndhlovu (1999:15). Die terminering van swangerskap omsluit morele aspekte en laat vrae ontstaan oor die begin van lewe, wat onder lewe verstaan word, watter waarde aan watter vorm van lewe geheg behoort te word en of lewe beskerm moet word al dan nie (Le Roux, 1995:149).

\section{Die aborsiedebat}

Volgens Kretzschmar en Hulley (1998:94-96) is drie uiteenlopende standpunte ten opsigte van die terminering van swangerskap wêreldwyd en in Suid-Afrika geïdentifiseer:

TABEL 2

\section{UITEENLOPENDE STANDPUNTE TEN OPSIGTE VAN ABORSIE}

\begin{tabular}{|l|l|}
\hline Pro-lewe-beweging & $\begin{array}{l}\text { Hierdie standpunt ondersteun eerbied vir lewe en die feit dat die terminering van } \\
\text { swangerskap 'n morele saak is, en dat dit dus met afkeur bejeën moet word. }\end{array}$ \\
\hline Pro-keuse-beweging & $\begin{array}{l}\text { Die opvatting van hierdie groep mense is dat die swanger vrou die reg het om oor } \\
\text { 'n ongewenste swangerskap te besluit. }\end{array}$ \\
\hline $\begin{array}{l}\text { Beperkte } \\
\text { geselekteerde } \\
\text { aborsie }\end{array}$ & $\begin{array}{l}\text { Die fetus se reg op lewe word gerespekteer met inagneming van regverdigbare } \\
\text { gevalle waarin die terminering van swangerskap noodsaaklik is. Aborsie is nie } \\
\text { slegs 'n mediese en wetlike saak nie, maar word gegrond op morele oortuigings. }\end{array}$ \\
\hline
\end{tabular}

Hierdie uiteenlopende oortuigings met betrekking tot aborsie en hoedanig dit mense se houdings ten opsigte van aborsie beïnvloed, beklemtoon die morele dilemma van aborsie (Ndhlovu, 1999:18). Alhoewel die jarelange konflik oor aborsie in die politieke arena van die samelewing gesentreer is, is konsensus oor en die oplossing van die probleem nie in wetgewing geleë nie (Schlossberg \& Achtemeier, 1995:3). Die stryd oor aborsie duur voort ongeag die optrede van 
politici en howe, aangesien dit vrae wat om geloofsoortuigings en die betekenis van lewe sentreer, ontlok.

\section{Mediese aspekte}

Op mediese gebied ontlok die terminering van swangerskap op versoek bepaalde moreel-etiese vrae waarop geen eenvoudige antwoorde bestaan nie. Die mediese tegnologie het nie net verfyning in aborsietegnieke tot gevolg nie, maar ook positiewe gevolge vir die fetus, want die fetus tree hierdeur meer prominent op die voorgrond as in die verlede. Dit is vir die medikus belangrik om nie weg te skram van die feit dat lewe reeds by bevrugting begin nie (Le Roux, 1995:161). Medici weet dat daar reeds vanaf die oomblik dat die spermsel en eiersel verenig, 'n onafhanklike, selfbeginnende biologiese entiteit bestaan en dat hulle in staat is om na inplanting die teenwoordigheid en aktiwiteit van die entiteit waar te neem. Weens mediese en tegnologiese vooruitgang is die lewe van vroeggebore babas " $n$ groter werklikheid en word lewensvatbaarheid op 28 weke na konsepsie gestel (Le Roux, 1995:95). Omdat kennis van fetale ontwikkeling voortdurend toe neem en geen werklike onderskeid tussen verskillende stadiums gemaak kan word nie, bestaan daar verskillende standpunte daaroor.

Diegene wat by die primêre fisiese versorging van die aborsiepasiënt betrokke is, word die meeste deur die terminering van swangerskap geraak. Verpleegkundiges en mediese praktisyns ervaar dikwels ambivalensie ten opsigte van die aborsieprosedure (Le Roux, 1995:108). Nogtans is alle verpleegkundiges professioneel en eties verplig om ingevolge wetgewing (Verpleging Wet, 50/1978) pasiënte voor en na ' $n$ prosedure te verpleeg, ongeag enige afkeer daarvan, aldus Dondashe (2001:2). Aborsie is een van die prosedures waaroor die geneesheer moet nadink, omdat hy sy optrede eties moet kan verantwoord (Le Roux, 1995:108).

\section{Maatskaplike aspekte}

Uit 'n ondersoek van Le Roux (1995:180) blyk dit dat aborsie ' $n$ verlaging in die moraliteit van die samelewing teweegbring. Wettige aborsie op versoek lei tot ' $n$ aborsiementaliteit wat ' $n$ verandering in die geestesingesteldheid van mense teweegbring. Dit impliseer dat aborsie oor die algemeen in die samelewing aanvaar word; dat skuldgevoelens kan ontbreek; dat aborsie gelykgestel kan word aan kontrasepsie; en dat 'n onsensitiwiteit vir die fetus kan ontstaan. In die lig van die huidige tendens in Suid-Afrika, soos uiteengesit deur Kretzschmar en Hulley (1998:90), naamlik die toenemende geboortesyfer, armoede, werkloosheid en die verbrokkeling van die gesins- en gemeenskapslewe, bestaan die gevaar dat promiskuiteit deur aborsie op versoek bevorder word (Le Roux, 1995:184).

Die maatskaplike gevolge van aborsie is gekompliseerd en dit kan die vrou wat aborsie ondergaan het, asook haar familie, op die lang termyn ernstig benadeel ten opsigte van intense hartseer, skuldgevoelens, ambivalensie, moedeloosheid en depressie. Geheimhouding kan die vrou wat aborsie ondergaan het, emosioneel vernietig (Ndhlovu, 1999:19). Daar word gedink aan getroude vroue wat sonder die medewete van hulle eggenote, asook minderjariges wat sonder die medewete van hulle ouers of voogde, wettige aborsies kan ondergaan. Weens die intense morele aanslag daarvan, los die terminering van swangerskap maatskaplike probleme nie werklik op nie, maar bevorder dit eerder in sommige gevalle.

\section{Godsdienstige aspekte}

Aborsie is ' $n$ komplekse en sensitiewe saak wat ' $n$ verskeidenheid geloofsoortuigings raak (Mkhize, 2000:98). Kerke het deurgaans teen aborsie gewaarsku, aangesien die fetus van die begin af as ' $n$ menslike wese beskou is. Hedendaagse aborsiewetgewing ontlok hewige teenkanting van 
die kant van kerke waarvan die regering kennis moet neem (Le Roux, 1995:164, Schlossberg \& Achtemeier, 1995:4). Dit is algemeen bekend dat die terminering van swangerskap teen alle christelike moraliteit indruis, sowel as teen die moraliteit van die tradisionele Jode, Moslems, Hindoes en verskeie ander gelowe (Dondashe, 2001:3). Alhoewel kerke oor die hantering van die aborsieprobleem verskil, kan die kerk hom nie daarvan distansieer nie. Die kerk het ' $n$ verantwoordelikheid om waardes en norme in die samelewing te help verwoord en in stand te hou (Le Roux, 1995:172).

\section{Kulturele aspekte}

Die demokratiese bedeling in die land het ' $n$ kultuur van menseregte geskep. Verskaffing van aborsiedienste aan die Afrika-vrou as deel van haar demokratiese reg volgens die Grondwet, kan tot spanning en teenstrydigheid binne Afrika-families en -gemeenskappe lei. Manxaile (1998:3) is van mening dat die aanvaarding van aborsiedienste binne sodanige gemeenskappe, veral met die oog daarop om die kwaliteit van haar lewe te verbeter, nooit uitsluitlik die besluit van die swanger vrou mag wees nie. Die toepassing van Westerse demokratiese waardes met die klem op indiwiduele menseregte behoort bemiddel te word in erkenning aan die Afrika-kultuur wat ander waardes huldig (Manxaile, 1998:3). Die tradisionele Afrika-denke is nie dualisties van aard nie; dit fokus op die gesamentlike eerder as die onderskeie aspekte; interafhanklikheid en harmonie tussen mense onderling asook tussen mense en hulle natuurlike omgewing (Kretzschmar \& Hulley, 1998:34).

Aborsie op versoek is vreemd in die Afrika-kultuur met sy eiesoortige tradisies en gewoontes (Dondashe, 2001:3). Derhalwe is die Afrika-vroue weens dergelike toegewings blootgestel aan vryhede en kan hulle eksperimenteer en ervaar wat voorheen vir hulle geheel en al onbekend was (Manxaile, 1998:10).

\section{Etiese aspekte}

Etiese aspekte ten opsigte van die terminering van swangerskap handel oor die begin van lewe, wat onder lewe verstaan word; watter waarde aan lewe geheg word; en of lewe beskerm moet word al dan nie. Hierdie aspekte word vervolgens aan die hand van Le Roux (1995:149-157) en Ndhlovu (1999:15) uitgelig.

Die lewensvatbaarheid en morele status van die fetus is ernstige knelpunte, aangesien onsekerheid oor die wenslikheid van fetusse in verskillende ontwikkelingstadiums bestaan. Die fetus het op 12 weke reeds volledig tot ' $\mathrm{n}$ menslike vorm ontwikkel. Lewensvatbaarheid in die reg word op 28 weke en in die mediese wetenskap op 22 weke gestel. Aangesien die moontlikheid bestaan dat die fetus op hierdie stadium buite die moederliggaam kan oorleef, word dit as ' $\mathrm{n}$ aanvaarbare kriterium vir morele status aanvaar. Lewensvatbaarheid kan nie sonder meer as kriterium vir morele status aanvaar word nie, aangesien die tydperk daarvan vervroeg word namate ontwikkeling in die mediese wetenskap en tegnologie plaasvind. Geen wetenskaplike verklaring word gegee vir die rede waarom aborsies tot op 12 weke van swangerskap toegelaat word nie, maar dit wil voorkom of die fetus hoër morele status vanaf 12 weke geniet, alhoewel dit nie in hierdie stadium as lewensvatbaar beskou word nie. Die morele status van die fetus is ' $n$ belangrike besprekingspunt in die aborsiedebat wat tot onbeantwoorde vrae lei.

Eerbied vir lewe is op godsdienstige waardes gegrond, maar daar is ook ongelowiges wat aan die onaantasbaarheid van die menslike lewe glo. Mense kan dus in die heiligheid van menslike lewe glo, ongeag of hulle gelowiges is al dan nie, en dus teen aborsie gekant wees. Volgens Le Roux (1995:156) is daar ' $n$ neiging in Suid-Afrika te bespeur dat mense hulle al hoe minder aan waardes en norme steur. Mense wil vry wees van godsdiens, en daarom speel menslike oorwegings ' $n$ 
toenemend belangrike rol in die bepaling van die etiek. Vrye seksuele uitlewing speel ' $n$ oorheersende rol terwyl die waarde van verantwoordelike seksualiteit in wetenskaplike en populêre artikels nie aandag geniet nie. Gevolglik verkies die mens vryheid in sy/haar seksuele gedrag, en indien die vrou swanger raak, moet aborsie op versoek vryelik beskikbaar wees sodat die onwelkome gevolg uit die weg geruim kan word. Die indiwidu streef na vryheid in alle opsigte en wil losgemaak wees van wette wat sy/haar gedrag beperk. Omdat menseregte prioriteit geniet, word daar selfs na veilige aborsies as basiese menseregte verwys. Die reg van vroue om beheer oor hulle eie liggame te verkry en om 'n besluit ten opsigte van swangerskap te kan neem, word beklemtoon, maar vroue se verantwoordelikheid ten opsigte van die gevolge van onbeskermde seks word soms genegeer. Enersyds is voorbehoedmiddels vryelik beskikbaar, maar andersyds word ' $n$ beroep op vroue gedoen om verantwoordelik op te tree. Adolessente en ongetroude jongmense moet weet dat seksuele omgang in die huwelik tuishoort, maar indien hulle egter seksueel aktief is, moet hulle voorsorg tref om hulle teen ongewenste swangerskap en seksueel oordraagbare siektes te beskerm (Le Roux, 1995:183).

Etiek is nie staties nie en verander na gelang van veranderinge in die samelewing. Indien die intrinsieke waarde van menslike lewe en die respek wat dit verdien, nie erken word nie, kan die etiese kode nie effektief wees nie (Ndhlovu, 1999:48). Die meeste etiese knelpunte kan bevredigend opgelos of verklaar word as konsensus oor die verskillende vraagstukke sou bestaan. Dog is die menings daaroor uiteenlopend van aard en bestaan daar twyfel of dit ooit versoenbaar sal wees.

\section{Bevolkingsbeleid en gesinsbeplanning}

Aborsie en kontrasepsie moet van mekaar onderskei word. Albei beoog beperking van geboortes, dog verskil die metodes en redes radikaal van mekaar. Kontrasepsie fokus op die voorkoming van konsepsie, terwyl aborsie op die terminering daarvan fokus (Kretzschmar \& Hulley, 1998:85).

Die debat oor kontrasepsie en aborsie word wêreldwyd gevoer - ook in Suid-Afrika. Elke egpaar mag besluit oor die aantal kinders wat hulle wil hê, maar dit is ook hulle verantwoordelikheid om die kinders behoorlik te versorg en op te voed. Die staat het die verantwoordelikheid en reg om maatreëls in te stel en programme te implementeer om balans tussen hulpbronne en bevolkingsgetalle in belang van alle persone te verseker. Voorkoming is die moeilike, maar proaktiewe weg wat gevolg behoort te word. Aborsie kan as ' $n$ maklike uitweg beskou word, maar die benadering moet so ver moontlik vermy word (Le Roux, 1995:218, 266). Aborsie is ' $n$ maatskaplike probleem met verreikende gevolge vir samelewings, en alles moontlik behoort gedoen te word om te voorkom dat aborsie nie as kontrasepsiemetode gebruik word nie.

Gesinsbeplanningsprogramme in Suid-Afrika moet deeglik beplan en uitgevoer word met inagneming van die kulturele diversiteit van die land. Dit moet in gedagte gehou word dat aborsiewetgewing nie as ' $\mathrm{n}$ gesinsbeplanningsmetode aangewend kan word nie (Wet op Keuse oor die Beëindiging van Swangerskap, Wet 92 van 1996, 1996c:1302). In talle kringe heers kommer oor die snelle bevolkingsgroei in die land, en aanspraak is daarop gemaak dat die wettiging van aborsie die bevolkingsgroei sal teëwerk (Le Roux, 1995:50). Doeltreffende gesinsbeplanningsprogramme en die gebruik van kontrasepsiemetodes word beklemtoon as teenvoeter daarvoor dat vroue en hulle naasbestaandes op lang termyn nadelig deur die onuitwisbare gevolge van die terminering van swangerskap geraak word.

\section{SAMEVATTING}

Die literatuur bevestig dat aborsie geen nuwigheid is nie. Dit is so oud soos die mensdom self, maar dit het in ' $n$ verskeidenheid vorme en stadiums na gestalte gekry totdat dit vandag in Suid- 
Afrika gewettig is. Ten spyte van wetgewing, los aborsie nie die probleem van ongewenste swangerskap op nie. Aborsie kan voorkom of beperk word indien gesinsbeplanningsprogramme en kontrasepsiemetodes werklik effektief deur die meerderheid vroue gebruik word. Daar moet dus gefokus word op opvoedingsprogramme waardeur kinders en jongmense met lewensvaardighede bemagtig kan word. Kennis rakende aspekte soos seksueel oordraagbare siektes, seksualiteit, voorhuwelikse en buitehuwelikse seksuele gemeenskap en ongewenste swangerskappe asook die gevolge daarvan is in hierdie hedendaagse samelewing noodsaaklik. Volwassenes behoort ook bewus gemaak te word daarvan dat die terminering van swangerskap ' $n$ werklikheid in die daaglikse lewe is sodat hulle hul nie daarvan distansieer nie, maar gesprekke daaroor by die opvoeding van kinders insluit.

Daar is geen klinkklare antwoorde op vrae rakende aborsie in die geheel nie. Soos in die vroegste geskiedenis sal standpunte ten opsigte van aborsie uiteenlopend bly, aangesien daar werklik getwyfel word aan die versoenbaarheid van die verskillende standpunte wat aandui dat aborsie 'n morele dilemma in Suid-Afrika geword het, soos ook in die res van die wêreld.

\section{BIBLIOGRAFIE}

ABORTION STATISTICS. 2000. London: The Stationery Office.

ANON. 1998. Hospitale kan nie vraag na aborsie hanteer. Beeld, 7 Januarie.

DAVEL, C.J. 2000. Introduction to child law in South Africa. Landsdowne: Juta \& Co Ltd.

DE PINHO, H. \& HOFFMAN, M. 1998. Termination of pregnancy - understanding the new Act: women's health. Continuing Medical Education Journal, 16(8):786-788.

DE VYNCK, S. 1999. Beraad aan adolessente dogters wat ' $n$ terminasie van swangerskap wil ondergaan. Johannesburg: Randse Afrikaanse Universiteit. (MEd Skripsie)

DONDASHE, V.I. 2001. The experience of registered nurses in the pre-counseling of pregnant women contemplating termination of pregnancy. Port Elizabeth: University of Port Elizabeth. (Mini-treatise - MCur)

FORREST, G.M. 1994. Emotional distress in women before and after therapeutic terminations of pregnancy. An investigation into the need for pre- and post abortion counseling. Cape Town: University of Cape Town. (MSocSc Dissertation)

GELDENHUYS, J. \& DE LANGE, N. 2001. Swart Oos-Kaapse adolessente se ervaring van swangerskapterminasie. South African Journal of Education, 21(2):92-98.

GUTTMACHER, A. 1999. Teenage pregnancy: overall trends and state-by-state information. USA: Alan Guttmacher Institute.

HAASBROEK, B. 1999. Wat sal gebeur as ek aborsie kies? Finesse, 7 Junie.

HAWTHORNE, L. 1982. The crime of abortion: A historical and comparative study. Pretoria: University of Pretoria. (Thesis - LL.D.)

KRETZSCHMAR, L. \& HULLEY, L. 1998. Questions about life and morality. Pretoria: JL van Schaik.

LE ROUX, J.P. 1995. Aborsie in Suid-Afrika: 'n Maatskaplike werk perspektief. Bloemfontein: UOVS. (PhD Proefskrif)

LOUW, D.A., VAN EDE, D.M. \& LOUW, A.E. 1999. Menslike ontwikkeling. Kaapstad: Kagiso. 
MANXAILE, A. 1998. Xhosa per-urban women's views on abortion as a human right: implications for a pro-impilo theological discourse on the choice of termination of pregnancy Act, no 92 of 1996, South Africa. Pietermaritzburg: University of Natal. (Dissertation - M.Th).

Mc CULLOCH, U.R. 1996. Women's experiences of abortion in South Africa: an exploratory study. Cape Town: University of Cape Town. (Dissertation - M.A.)

MKHIZE, B.A. 2000. The termination of pregnancy Act of 1996: A theological ethical evaluation of abortion on demand. Pretoria: University of Pretoria. (Dissertation - M.Th.)

MOGANO, M.S. 1999. Factors influencing the decision of teenagers to terminate their pregnancies. Johannesburg: Rand Afrikaans University. (Mini-dissertation - M. Soc.Work

MOJAPELO-BATKA, E.M. 2000. Voluntary termination of pregnancy: Meanings and coping with emotional impact of perceived or anticipated social sanctions. Hammanskraal: Medunsa (Dissertation - M.Sc.).

NDHLOVU, M.P. 1999. Nurses' experiences of abortion: an exploratory study of nurses experiences in assisting with termination of pregnancy in South Africa and Zambia. Western Cape: University of Cape Town. (Thesis - M.Cur.)

RAU, L. 1996. The constitutionality of abortion limiting legislation in South Africa. Pretoria: University of South Africa. (Dissertation - Master of Laws).

RULASHE, L. 1999. The psycho-social dimensions of abortion amongst Xhosa speaking women. Port Elizabeth: University of Port Elizabeth. (Disseration - M.A.)

SCHLOSSBERG, T. \& ACHTEMEIER, E. 1995. Not my own. Michigan: William Eerdmans Publishing Company.

SCWINDACK, R.M. Editorial 1995. The abortion debate revisited in South African context: Geneeskunde, 37(5):5-10.

SEKUDU, J. 2001. Abortion: a social work study. Pretoria: University of Pretoria. (DPhil Thesis)

SUID-AFRIKA. 1975. Wet op vrugafdrywing en sterilisasie, no 2 van 1975. Staatskoerant no 16. Pretoria.: Staatsdrukker.

SUID-AFRIKA. 1996(a). Grondwet van die Republiek van Suid-Afrika. No 108 van 1996. Pretoria.: Staatsdrukker.

SUID-AFRIKA. 1996(b). Wetsontwerp op die beëindiging van swangerskap, (WB80-96). Pretoria.: Staatsdrukker.

SUID-AFRIKA. 1996(c). Wet op keuse oor die beëindiging van swangerskap. No 92 van 1996. Pretoria.: Staatsdrukker.

VAN ROOYEN, C.A.J. 1998. Abortion: a study of final-year social work students' responses to abortion-related issues. Social Work / Maatskaplike Werk, 34(3):295-306.

Me HS Humpel, is 'n PhD-student en hoof maatskaplike werker by Potchefstroom Hospitaal, Noordwes Provinsie, Departement Gesondheid en Professor Herman Strydom is hoof van die maatskaplikewerkafdeling by die Skool vir Psigo-sosiale Gedragswetenskappe, Potchefstroomkampus van die Noordwes-Universiteit. 